\title{
Synthesis and liquid crystalline behaviour of substituted (E)-phenyl-4-(phenyldiazenyl) benzoate derivatives and their photo switching ability
}

\author{
Gurumurthy Hegde, Govindaswamy Shanker, S. M. Gan, A. R. Yuvaraj, Syed \\ Mahmood \& Uttam Kumar Mandal
}

To cite this article: Gurumurthy Hegde, Govindaswamy Shanker, S. M. Gan, A. R. Yuvaraj, Syed Mahmood \& Uttam Kumar Mandal (2016) Synthesis and liquid crystalline behaviour of substituted (E)-phenyl-4-(phenyldiazenyl) benzoate derivatives and their photo switching ability, Liquid Crystals, 43:11, 1578-1588, DOI: 10.1080/02678292.2016.1189001

To link to this article: http://dx.doi.org/10.1080/02678292.2016.1189001

\section{曲 Published online: 08 Jun 2016.}

Submit your article to this journal $\llbracket$

Џll Article views: 118

Q View related articles $\longleftarrow$

View Crossmark data ¿ 


\title{
Synthesis and liquid crystalline behaviour of substituted (E)-phenyl-4- (phenyldiazenyl) benzoate derivatives and their photo switching ability
}

\author{
Gurumurthy Hegde ${ }^{a}$, Govindaswamy Shanker ${ }^{b}$, S. M. Ganc, A. R. Yuvaraj ${ }^{c}$, Syed Mahmood ${ }^{d}$ \\ and Uttam Kumar Mandal ${ }^{\mathrm{d}}$ \\ ${ }^{a}$ BMS R and D Centre, BMS College of Engineering, Bangalore, India; bepartment of Studies in Chemistry, Bangalore University, Central \\ College Campus, Bangalore, India; 'Faculty of Industrial Sciences and Technology, Universiti Malaysia Pahang, Kuantan, Malaysia; \\ dDepartment of Pharmaceutical Technology, Kulliyyah of Pharmacy, International Islamic University, Kuantan, Malaysia
}

\begin{abstract}
Azobenzene derivatives containing phenyl/4-halogen-phenyl 4-\{(E)-[4-(pent-4-en-1-yloxy)phenyl] diazenyl\}benzoate group with different electronegative substituent $(\mathrm{H}, \mathrm{F}, \mathrm{Cl}, \mathrm{Br}$ and $\mathrm{I})$ at other end was synthesised. These azo-based benzoate derivatives have been characterised by FTIR, ${ }^{1} \mathrm{H}-\mathrm{NMR}$, ${ }^{13} \mathrm{C}-\mathrm{NMR}$, elemental analyser, POM and UV-Vis spectroscopy. Photosaturation at $358 \mathrm{~nm}$ obtained after $82 \mathrm{~s}$ of UV irradiation and the longest thermal back relaxation time of $45 \mathrm{~h}$ recorded by UVVis. The azo derivative could be possible photolock under UV light, as observed by the improved thermal back relaxation time. The resulting photolockable chain of azobenzene might prove valuable in the development of optical device application. These azobenzene moieties also exhibit liquid crystalline behaviour with respect to the halogen substitution as an electron withdrawing group shows that strong structure property relationship exists among them.
\end{abstract}

\section{ARTICLE HISTORY}

Received 12 November 2015 Accepted 9 May 2016

\section{KEYWORDS}

Photoisomerisation; azobenzene derivatives; liquid crystals; storage device; thermal back relaxation; photolock

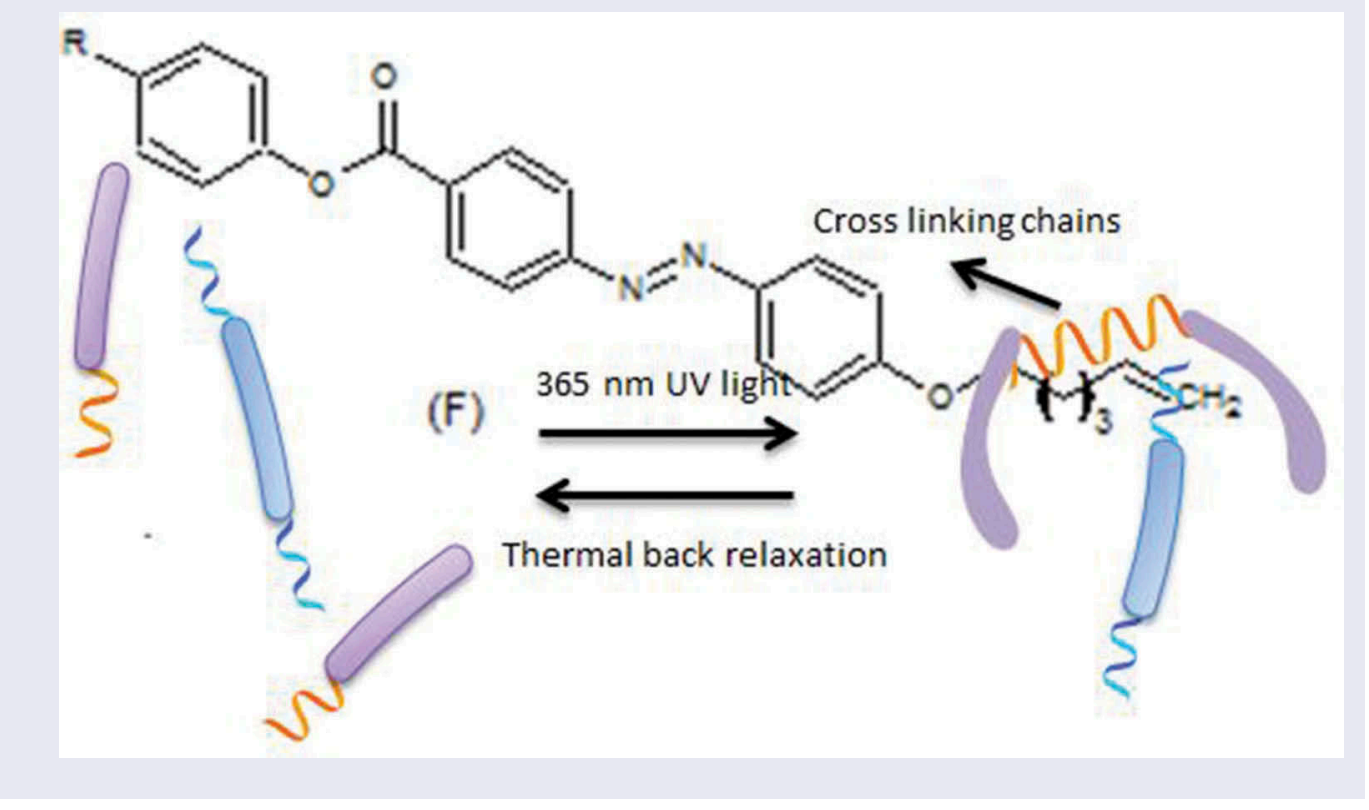

\section{Introduction}

Organic photochromic compounds have been attracted a great deal of attention over the last few years due to their potential use in a variety of optical devices employing photoinduced phase transition.[1-6] This process arises from the reversible trans-cis-trans photoisomerisation, resulting in the molecular orientation of nematic liquid crystal to higher orientational entropy (disorder).[7] This allows organic compound containing azo chromophores to be utilised in storing information optically. For optical storage device, azobenzene with long thermal back relaxation is a pre-requisite [8-11], that is, long recovery time from the excited (cis) state to the initial (trans) state of the system after illumination with UV light of wavelength $365 \mathrm{~nm}$. As to enhance the optical storage features, a

CONTACT Gurumurthy Hegde $\otimes$ murthyhegde@gmail.com $\mathrm{B}$ BMS R and D Centre, BMS College of Engineering, Bull Temple Road, Bangalore 560019, India

๑ 2016 Informa UK Limited, trading as Taylor \& Francis Group 
large number of fundamental and technology-driven studies have been done.[12-24] The first possibility in this engineering process lies on the chemical synthesis, where different functional groups can be attached to azobenzene molecules, improving their photochemical characteristic. Photopolymerisation of liquid crystal (LC) has been known for long time.[25-28] It was suggested that the successful photolocking of LC molecules containing polymerised chain provide new strategy for the creation of permanent optical storage devices.[26,27] Orientation of the LC molecules can be varied both locally and optically patterned LC phase can be 'frozen in' by subsequent photolocking effect. However, photolocking as an approach to produce long thermal back relaxation have yet to be studied.[29,30] If alkene monomer is substituted by a moiety conducive in the generation of liquid crystal phases, then the resulting polymer may exhibit liquid crystalline phases. It is possible to make azo dye molecules with terminal alkene which comprise an unsaturated carbon-carbon bond to polymerise the molecules. Because illumination with UV light initiates photopolymerisation reactions, each azo monomer will join together at the unsaturated double bond to become long photopolymer chain of azobenzene. Their consequent large molecular mass relative to small molecule compounds produces unique physical properties.

The interest in photopolymerisation of azobenzene molecules also lead us to explore in our study on the effect of electronegativity among the halogene on photopolymerisation activity. Electronegativity is a well-known chemical property that describes the tendency of an atom or a functional group to attract electron (or electron density) toward itself. An atom's electronegativity is affected by both its atomic number and the distance at which its valence electrons reside from the charged nucleus. The higher the associated electronegativity number, the more an element or compound attracts electron towards it. Hence, it is worth to study the photoswitching behaviour of photopolymerisable azobenzene substituted with different electronegative atoms. These atoms are thought to withdraw electron density from the bonding $\pi$-type orbitals of the photochromic azo bridge $(-\mathrm{N}=\mathrm{N}-)$ in the centre of the molecule. A weak $-\mathrm{N}=\mathrm{N}-$ bond reduces the barrier for rotation around this bond, which should allow for more efficient inter-conversion since rotation is one of the two pathways (the other one being inversion) for isomerisation. According to $\mathrm{Pu}$ et al. [31], the atomic charge on $\mathrm{N}$ atom in $\mathrm{N}=\mathrm{N}$ bond bearing substituent display no correlation with the electron-withdrawing/ donating ability. In fact, the substitutions either by electron donors or by electron acceptor decrease the electron density on the $\mathrm{N}$ atom. It is remarkable that the electron density on the $\mathrm{N}$ atom decreases as the atoms electronegativity increases, signifying a considerable dependence on the electronegativity.[32]

In the light of these findings, a series of photolocking azobenzene with different electronegative substituent $\mathrm{R}(\mathrm{R}=\mathrm{F}, \mathrm{Cl}, \mathrm{Br}$ and $\mathrm{I})$ have been designed and compared them with the one unsubstituted ( $\mathrm{H}$ atom). The elements $\mathrm{F}, \mathrm{Cl}, \mathrm{Br}$ and $\mathrm{I}$, collectively known as halogen, are very important since one can tailor the materials with changing the electronegative for optical device applications. Their mesogenic behaviour was checked and photolocking with UV light was performed and its effect on thermal back relaxation was investigated.

\section{Experimental}

\subsection{Sample preparation}

The synthetic strategy is given in Scheme 1 for the preparation of target compounds (6-H, 6-F, 6-Cl, 6Br 6-I), which contains different halogen substitutions at the para-position with respect to the ester linkage. The structures of all the intermediates and final target molecules confirmed by different spectroscopic methods, viz IR spectra recorded using a Perkin Elmer (670) FTIR spectrometer, ${ }^{1} \mathrm{H}$ NMR $(400 \mathrm{MHz}),{ }^{13} \mathrm{C}$ NMR $(100 \mathrm{MHz})$ using Bruker and CHN elemental analyser using Leco \& Co.

\subsection{Investigation of phase behaviour and optical properties}

Phase transition of the compounds was studied by using polarising optical microscope. All experiments performed using Olympus BX 51 polarising optical microscope, the polarising optical microscope equipped with a Linkam Hotstage enabling in situ high temperature observations under polarised light. Samples were prepared on glass slide and covered with coverslip.

\subsection{Photoisomerisation studies}

Absorption spectra for photoisomerisation studies were recorded using an Ocean Optics HR-2000+ UV-Vis spectrophotometer. Kinetics of both trans-cis photoisomerisation and cis-trans thermal isomerisation studied for dilute solutions as well as in solid state. All the solution along with the synthesised compounds were 

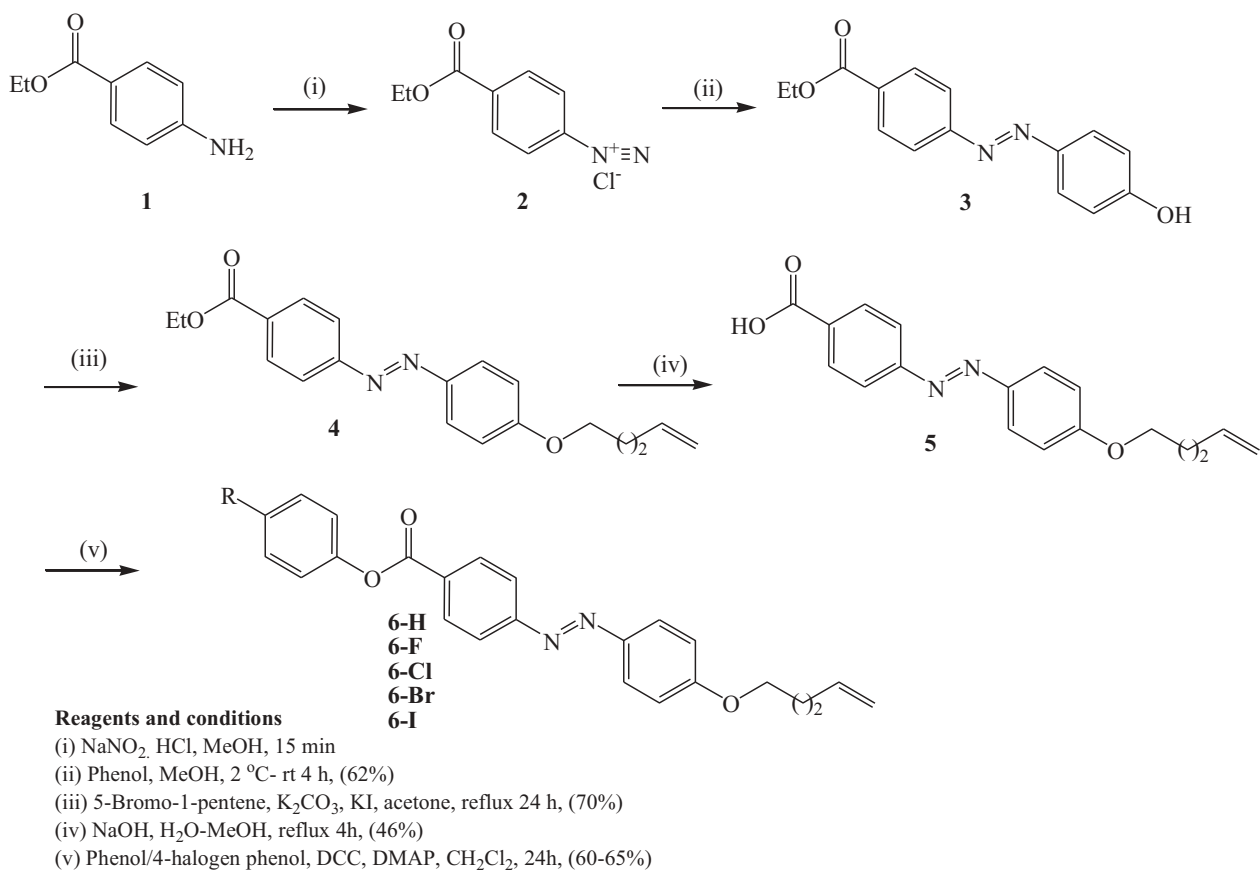

Scheme 1. Synthetic scheme of target compounds $6(\mathrm{H}, \mathrm{F}, \mathrm{Cl}, \mathrm{Br} \mathrm{I})$

prepared using chloroform and measured under air in the dark at room with temperature $\left(27 \pm 1^{\circ} \mathrm{C}\right)$ using $1 \mathrm{~cm}$ quartz cuvettes. The cuvettes were closed to avoid evaporation of the solvent and the solutions were not disturbed during the irradiation time. The solutions were irradiated with Hamamatsu light source at $365 \mathrm{~nm}$ using suitable filter UG11 and heat filter inserted to avoid any heating effects. Intensity passing through the filter measured to be $2 \mathrm{~mW} / \mathrm{cm}^{2}$, which was measured by a broadband power/energy meter model 13PEM001 (MELLES GRIOT) detector and power meter. The spectral data normalised for comparison between the samples. The absorption spectra of the compounds investigated here before and after illuminating with UV light.

\section{Results and discussion}

In order to demonstrate the effect of electronegativity on photocrosslinkable azobenzene, a series of azobenzene with locking alkene synthesised, bearing variable electronegative halogen with crosslinkable 1-pentene attached to its terminal end. Specifically, functionalised halogen with decreasing electronegativity side groups of fluorine $(\mathrm{F})$, Chlorine $(\mathrm{Cl})$, Bromine $(\mathrm{Br})$ and Iodine (I) attached in place of hydrogen $(\mathrm{H})$. The linker 1pentene moiety was chosen because of the double bond at one end of the molecule capable of undergoing polymerisation.

\subsection{Mesomorphic properties}

All the azobenzene system has alkene terminal group (1-pentene) and the observation with the help of polarising optical microscope exhibits liquid crystalline mesophases. On cooling from its isotropic state, the thread-like appearance which is characteristic of nematic $(\mathrm{N})$ phase evidences for the compounds 6-F, 6-Cl, 6-Br and 6-I followed by focal conic texture representing smectic A $(\mathrm{SmA})$ phase. However, in the case of $\mathbf{6 - H}$, where no electron withdrawing group exhibit only SmA phase as shown in Figure 1. Representative microscopic images for various phases are shown in the figure and thread-like behaviour as well as focal conic texture. It is to be noted that inclusion of electron withdrawing group is crucial for obtaining polymorphism liquid crystalline phases, whereas absences of electron withdrawing group exhibit only layered SmA phase. All the compounds (6-H to 6-I) exhibited enantiotropic liquid crystal phase and the transition temperatures are summarised in Table 1. All the compounds were stable even at high clearing temperatures, especially the compound $\mathbf{6 - C l}$ and $\mathbf{6 - B r}$ on periodic POM observation. Terminal substituted halogens are more polarisable and larger in size favourable for space filling concept giving raise to layered arrangement, the driving force for the formation of layered smectic phase is considered to be specific anisotropic interaction between unlike mesogenic units. [33-36] The melting temperature $\left(T_{\mathrm{m}}\right)$ of the series 

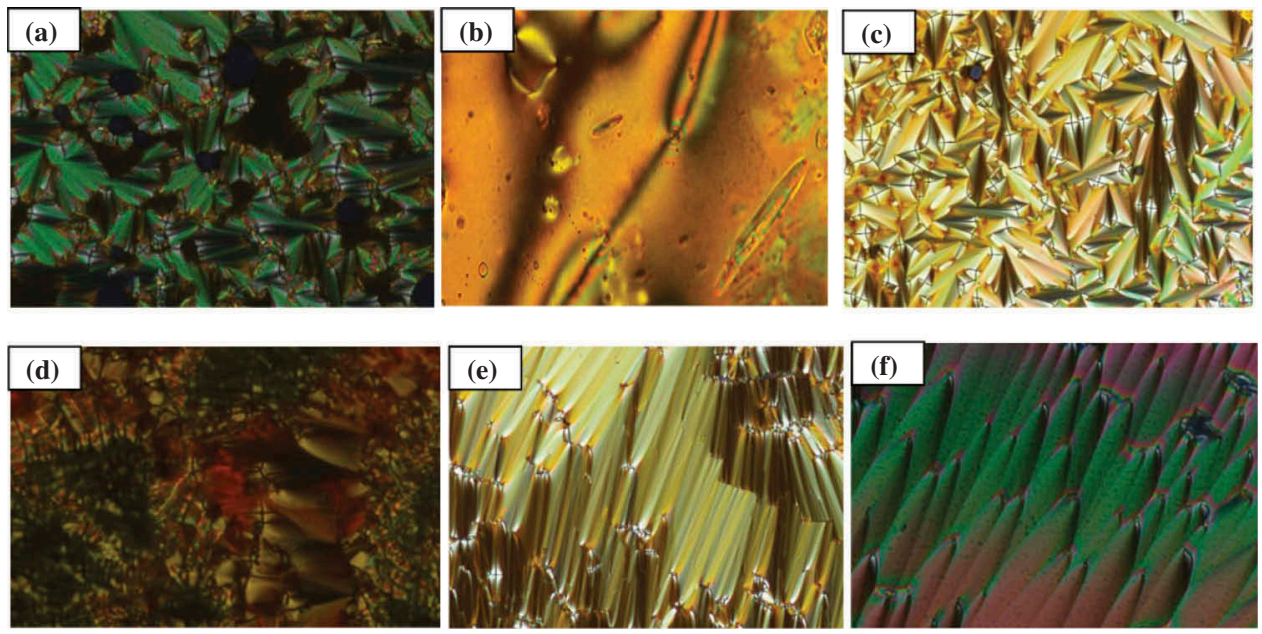

Figure 1. (colour online) Microphotographs (crossed polariser) of the textures observed at room temperature for the dyes at different temperature in the cooling cycles from isotropic phase of the compounds $6 \mathrm{H}-6 \mathrm{I}$. Focal conic images represents smectic $\mathrm{A}$ $(\mathrm{SmA})$ phase and thread-like appearance is for the nemtic (N) phases. Focal conic texture of SmA phase for $6-\mathrm{H}$ at $132^{\circ} \mathrm{C}(\mathrm{a})$, threadlike appearance represents nematic phase for $6-\mathrm{F}$ at $200^{\circ} \mathrm{C}(\mathrm{b}), \mathrm{SmA}$ phase for $6-\mathrm{F}$ at $152^{\circ} \mathrm{C}$ (c), SmA phase for $6-\mathrm{Cl}$ at $155^{\circ} \mathrm{C}(\mathrm{d}), \mathrm{SmA}$ phase for $6-\mathrm{Br}$ at $172^{\circ} \mathrm{C}$, SmA phase for $6-1$ at $180^{\circ} \mathrm{C}$ (f)

Table 1. Phase transition temperature $\left({ }^{\circ} \mathrm{C}\right)$ on both heating and cooling cycles of all the compounds as observed in OPM

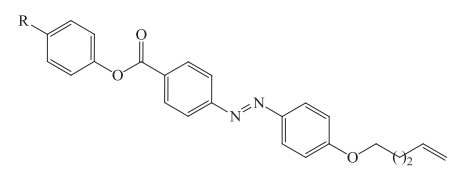

\begin{tabular}{lcccccccc}
\hline & & \multicolumn{7}{c}{ OPM observation } \\
\cline { 3 - 8 } Compounds & $-\mathrm{R}$ & $\mathrm{Cr}$ & $\begin{array}{c}\text { Heating } \\
\text { Cooling }\end{array}$ & SmA & $\begin{array}{c}\text { Heating } \\
\text { Cooling }\end{array}$ & N & $\begin{array}{c}\text { Heating } \\
\text { Cooling }\end{array}$ & Iso \\
\hline $6-\mathrm{H}$ & $\mathrm{H}$ & $*$ & 129 & $*$ & & - & 203 & $*$ \\
& & & 109 & & & & 201 & \\
$6-\mathrm{F}$ & $\mathrm{F}$ & $*$ & 131 & $*$ & 185 & $*$ & 205 & $*$ \\
& & & 98 & & 184 & & 203 & \\
$6-\mathrm{Cl}$ & $\mathrm{Cl}$ & $*$ & 143 & $*$ & 201 & $*$ & 257 & $*$ \\
& & & 117 & & 199 & & 256 & \\
$6-\mathrm{Br}$ & $\mathrm{Br}$ & $*$ & 153 & $*$ & 203 & $*$ & 254 & $*$ \\
& & & 121 & & 201 & & 253 & \\
$6-\mathrm{I}$ & $\mathrm{I}$ & $*$ & 160 & $*$ & 205 & $*$ & 238 & $*$ \\
& & & 130 & & 204 & & 237 & \\
\hline
\end{tabular}

Cr: crystalline phase; SmA: smectic A phase; N: nematic phase; Iso: isotropic phase, (*: phase exists; - : phase does not exist).

observed in the range of $95-160^{\circ} \mathrm{C}$ and clearing $\mathrm{POM}$ observation revealed that the compounds 6-F to 6-I show $\mathrm{N}$ and SmA phases, whereas 6-H exhibit only SmA phase. It is evident from the Table 1 that electron withdrawing halogen are crucial for polymesomorphic behaviour.

\subsection{Photoisomerisation studies}

Before UV irradiation, all compounds in solution featured absorption band at wavelength between 358$364 \mathrm{~nm}$ and a relatively low absorption around
$450 \mathrm{~nm}$. The former band correspond to $\mathrm{S}_{2} \leftarrow \mathrm{S}_{0}$ transition absorbs at $\sim 360 \mathrm{~nm}$ (corresponds to a symmetryallowed $\pi-\pi^{*}$ transition) whereas the latter band correspond to $S_{1} \leftarrow S_{0}$ transition appears as a weak band at $\sim 450 \mathrm{~nm}$ (correspond to a symmetry-forbidden $\mathrm{n}-\pi^{*}$ transition).[37-40] The trans isomer of $\mathbf{6 - H}$ has absorption maxima at $358 \mathrm{~nm}$ and there are no significant changes in the absorption spectra of halogen substituted compounds which are from the same group-17 of periodic table. This is contrary to our previous publication on fluorine addition into azobenzene-based ester, as there is a significant bathochromic shift as more number of fluorine atoms is added into the structure.[10,11]

Upon UV illumination, peak absorption at UV region (correspond to $\pi-\pi^{*}$ electron transition) decreased due to trans to cis isomer conversion, followed by slight increase in the peak around $450 \mathrm{~nm}$ (correspond to $\mathrm{n}-\pi^{*}$ electron transition). This phenomenon arises from the functionality of photochromic properties of azo group. All the compounds (6-H to 6-I) undergo trans-to-cis photoisomerisation following the $S_{1} \leftarrow S_{0}$ and $S_{2} \leftarrow S_{0}$ excitation.[34,35] Figure 2 illustrates the spectral changes for compound 6-H, 6-F, 6$\mathrm{Cl}, \mathbf{6 - B r}$ and 6-I monitored by UV-Vis during UV exposure.

The results reveal that 6-F took the shortest time for trans-to-cis conversion, which is $73 \mathrm{~s}$ whereas 6-I took the longest time, which is $91 \mathrm{~s}$. This spectral data confirmed the photoreaction, wherein the photoisomerisation process lead to a photostationary state. At this state, the cis-trans isomers ratio is dependent on the 

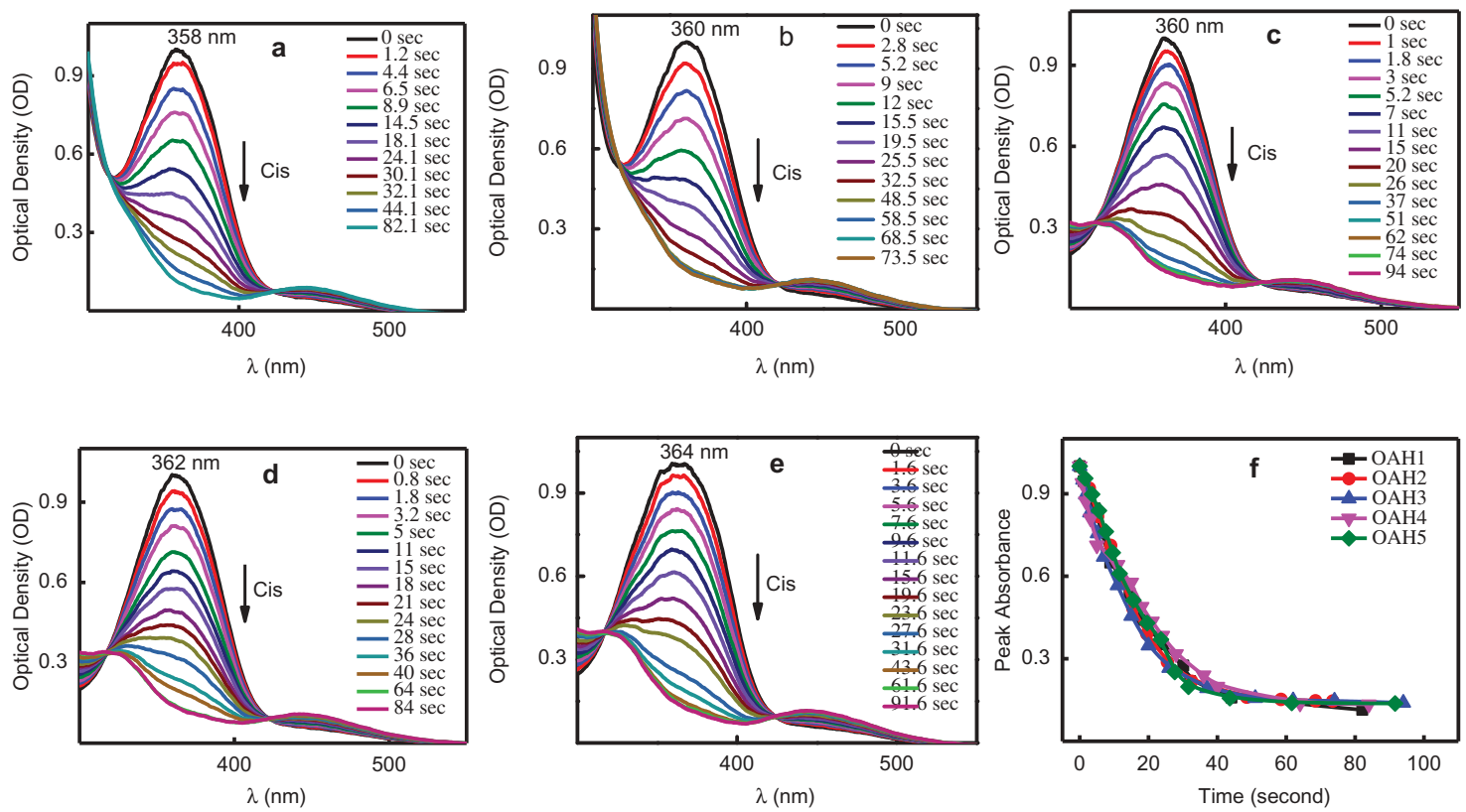

Figure 2. (colour online) Changes of absorption spectra during UV exposure; (a) -6-H, (b) -6-F, (c) -6-Cl, (d) -6-Br, (e) -6-I, (f) the plot of peak absorbance vs. time extracted from $a, b, c, d$ and $e$

wavelength used.[41] As, all the compounds show maximum absorption in the UV region, they give more than $85 \%$ of conversion efficiency after exposure to UV light at wavelength $365 \mathrm{~nm}$. Consider the case of 6-H, for example, $88 \%$ of the sample (in solution) have been converted to cis isomer after exposure to UV radiation for $82 \mathrm{~s}$. The conversion efficiency (CE) (it is also called as extent of photoisomerisation) of the trans-cis photoisomerisation is estimated from Equation (1).[42,43]

$$
C E=\frac{A\left(t_{0}\right)-A\left(t_{\infty}\right)}{A\left(t_{0}\right)} \times 100 \%
$$

here $A\left(t_{o}\right)$ is absorbance before UV and $A\left(t_{\infty}\right)$ is absorbance after UV. Table 2 shows the summary of time taken for the five azo derivatives for trans-cis photoisomerisation with their calculated conversion efficiency. Detailed kinetic description about first-order plots were given in later section of the manuscript.

The reverse transformation from cis to trans can be brought about by two methods: first method is by

Table 2. Time taken for the azo derivatives for $E-Z$ and $Z-E$ isomerisation with their calculated conversion efficiency

\begin{tabular}{lccc}
\hline Designation & $E-Z($ Time) $(\mathrm{s})$ & $Z-E($ Time) $(\mathrm{h})$ & CE (\%) \\
\hline $\mathrm{F}_{1}$ & 82 & 45 & 88.6 \\
$\mathrm{~F}_{2}$ & 73 & 28 & 85.4 \\
$\mathrm{~F}_{3}$ & 94 & 17 & 86 \\
$\mathrm{~F}_{4}$ & 84 & 12 & 86.6 \\
$\mathrm{~F}_{5}$ & 91 & 14 & 86.2 \\
\hline
\end{tabular}

keeping the solution in the dark to allow thermal back relaxation process to take place and the other method is by shining white light of higher wavelength.[37] To observe the thermal back relaxation process after molecules attaining photosaturation state, samples are left in the dark to allow cis-trans transformation. The effect of structural modification can be observed in their thermal back relaxation time. Figure 3 shows the spectral changes of 6-H to 6-I during thermal back relaxation process where the cis isomers return to trans. Among all, 6-H shows the longest thermal back relaxation time of $45 \mathrm{~h}$.

For trans-cis-trans photoisomerisation, it is necessary to measure first-order plot for chemical reaction. [44] Figure 4 shows the first-order plot which is measured by fitting the experimental data to the Equation (2) [39] at room temperature $25^{\circ} \mathrm{C}$.

$$
\ln \frac{A_{\infty}-A_{t}}{A_{\infty}-A_{o}}=-k_{c-t} t
$$

where $A_{t}, A_{0}, A_{\infty}$ are the absorbance at peak wavelength at time $t$, time zero and infinite time, respectively. The reaction was first-order in the time region indicated. But, it is also observed that it will deviate from the first-order curve at latter part of the reaction, mainly due to the long thermal back relaxation might affected the experimental temperature conditions (since this experiment is carried out in solution). Here, one can mainly observe the change in back relaxation time with respect to chemical structures. 

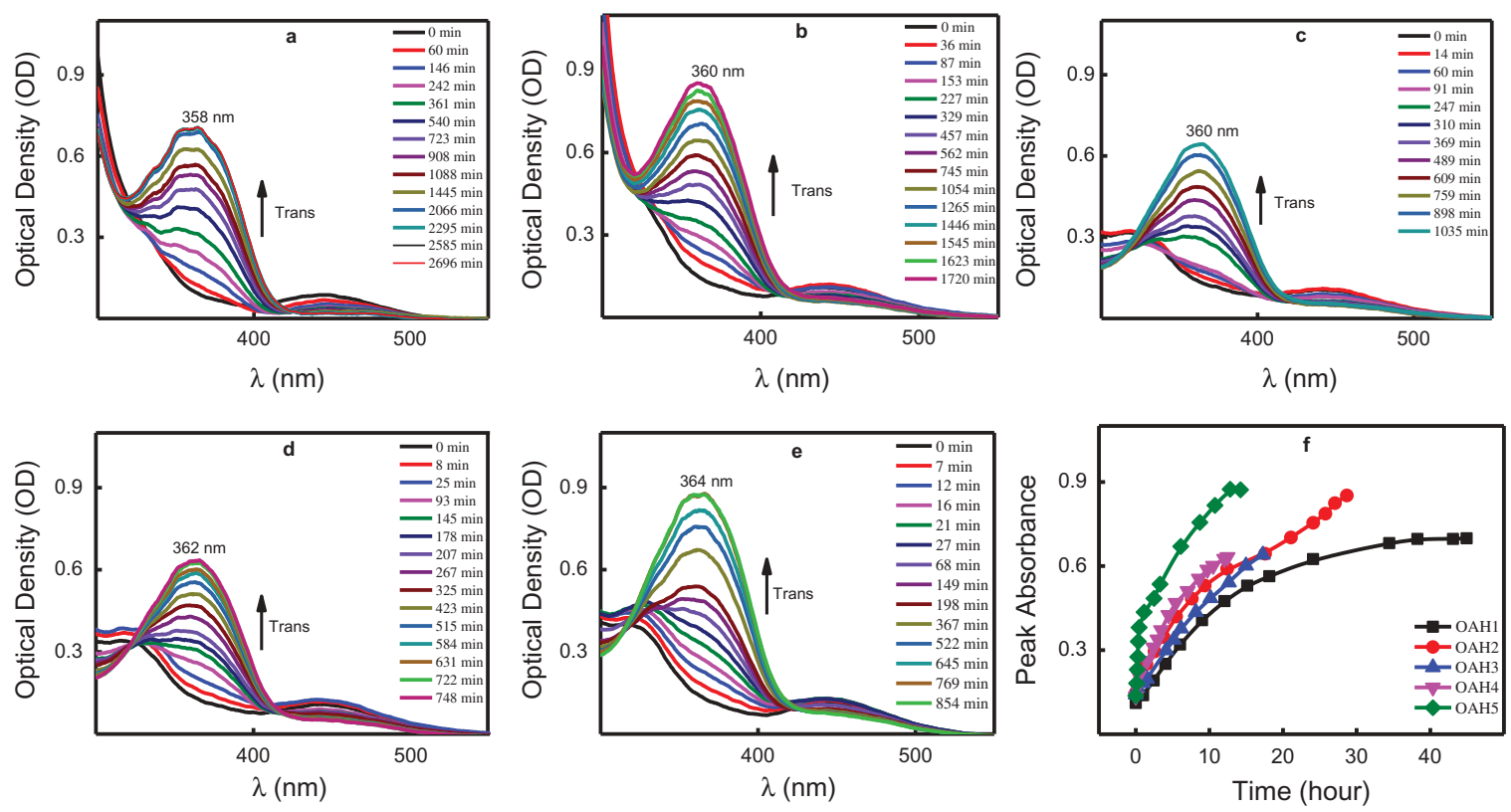

Figure 3. Changes of absorption spectra during thermal back relaxation; (a) - 6-H, (b) - 6-F, (c) - 6-Cl, (d) - 6-Br, (e) - 6-I, (f) the plot of peak absorbance vs. time extracted from $a, b, c, d$ and e

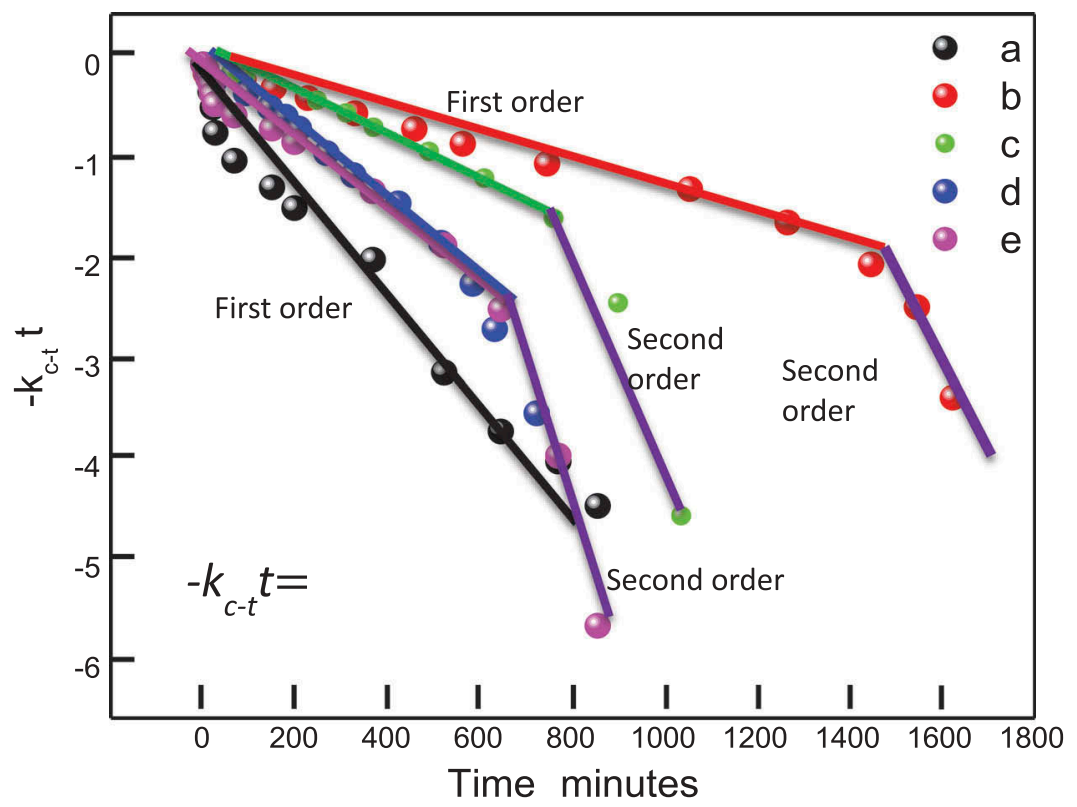

Figure 4. First-order plots for Z-E thermal isomerisation for reported compounds (a) -6-H, (b) -6-F, (c) -6-Cl, (d) -6-Br, (e) -6-I, (f) measured at room temperature $25^{\circ} \mathrm{C}$

This is also the best example to show the kinetic description of the compounds.

The long thermal back relaxation might be due to photolocking of 1-pentene terminal moiety, wherein, this moiety has the ability to undergo efficient photoinitiated polymerisation.[45] In addition to that, having a double bond at the alpha ( $\alpha$ ) position enhances the reactivity of azo derivative.[46] As a consequence, it absorbs the UV energy and initiates photopolymerisation in 6-H through formation of intermolecular lockable chains by the UV light at wavelength $365 \mathrm{~nm}$. In most cases, the photopolymerisation involve the production of singlet and triplet in excited state [45,47-49], which then react with other 1-pentene terminal moiety nearby. The photolocking effect subsequently creates an entangled polymeric network which restricts the cis isomers to go back to the original trans configuration. Thus, the geometrical restrictions should be a function of the crosslink moiety as shown in the proposed model in Figure 5. 


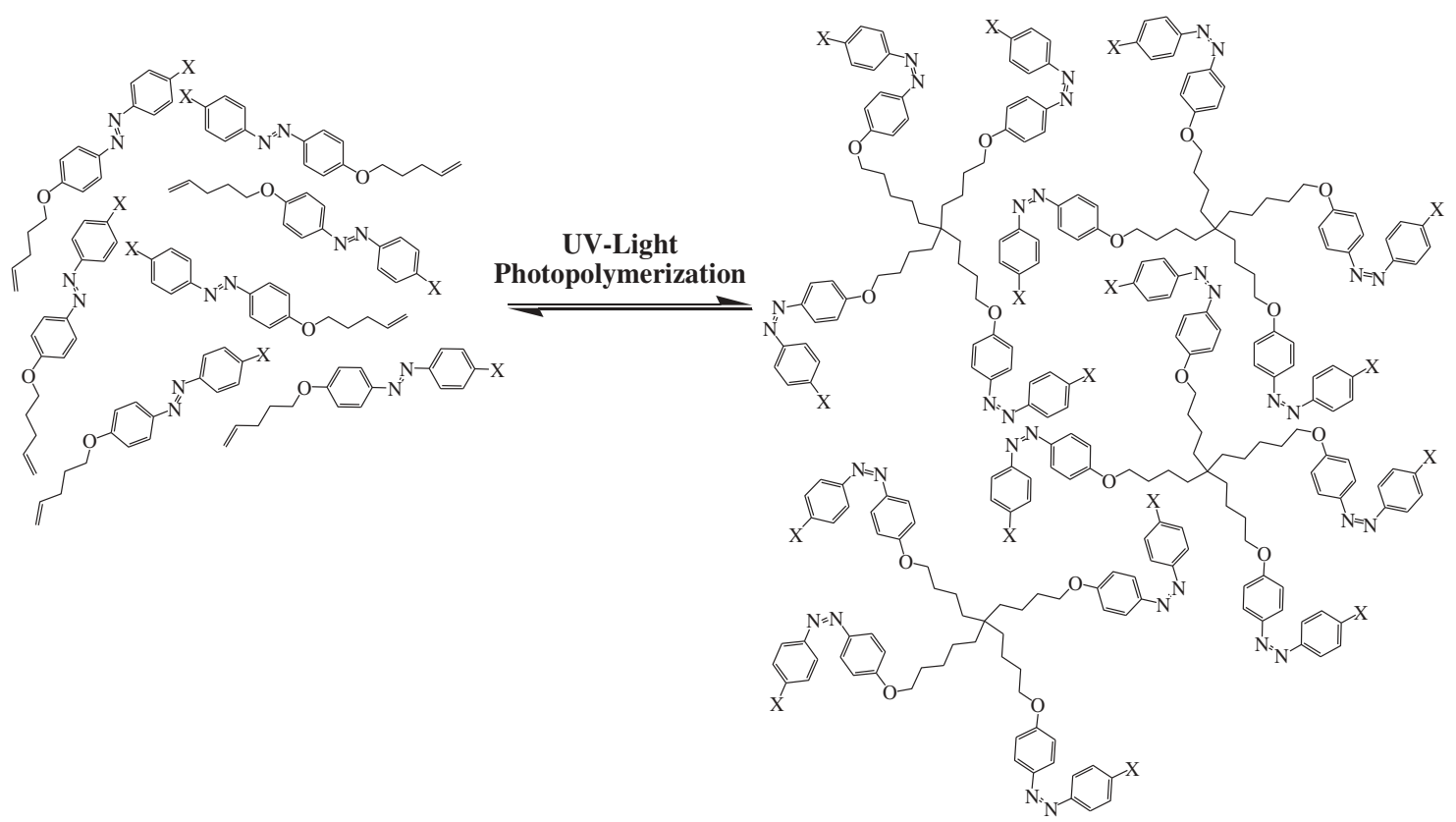

Figure 5. Photoinduced polymerisation model showing the photolocking effect observed in the molecules $(6-\mathrm{H}, 6-\mathrm{F}, 6-\mathrm{Cl}, 6-\mathrm{Br}, 6-\mathrm{I})$ in solution. Such system gives a long thermal back relaxation due to locking effects

With increase in atomic number down the group17 , the electronegativity decrease from $\mathrm{F}(4.0)>\mathrm{Cl}(3.0)$ $>\operatorname{Br}(2.8)>\mathrm{I}(2.5)$. 6-F characterised by fluorine substituent, the most electronegative group of all elements, gave $28.66 \mathrm{~h}$ of thermal back relaxation. One can see from Figure $3(\mathrm{~b}-\mathrm{e})$, as the electronegativity of halogen increased, the thermal back relaxation extended significantly from $14.23 \mathrm{~h}$ to $28.66 \mathrm{~h}$. Interestingly, these results are lower considerably in comparison to that of 6-H, indicating that the photolocking behaviour interacts with the different electronegativity of group17 elements. These might be the consequence of changes in the electron distribution on the $\mathrm{N}$ atom bearing halogen substituent group.[32] Needless to say, the photolocking is a useful method to improve the thermal back relaxation in azobenzene molecules. However, substitution of electronegative element as functional group does not extend thermal back relaxation in azobenzene with photocrosslinkable 1-pentene.

As soon as UV light of wavelength $365 \mathrm{~nm}$ is shined on them, energetically stable trans molecules convert to cis molecules, in other words system goes from order to disorder state.[8-11] Although exact reason is not much clear but we speculate that, here, with the effect of UV light, there might be the possibility of partial photo-locking effect as shown (Figure 6). Reverse phenomena of bringing them back to the original trans configuration is not easy and it takes very long time may be due to the mechanism of locking. Further investigation in this direction is in progress and will be reported elsewhere.

\section{Conclusions}

In conclusion, the nature of 1-pentene terminal group has a strong influence on the thermal back relaxation process. Electron withdrawing groups will help to induce liquid crystallinity. Both photochromic azo group and electronegative substituents found to induce strong photoisomerisation. This study gives an important aspect to utilise the photochemically induced process for long thermal back relaxation, mainly due to 1pentene terminal group appears to photo induce through the formation of intermolecular cross-linked chains. Further, on fine tuning the terminal cross-linker tail, one can able to get permanent locking effect in which optical storage devices can last longer.

\section{Experimental section}

All the compounds, ethyl 4-amino benzoate (Fluka), sodium nitrite (Fluka), phenol (Merck), Hydrochloric acid (Merk), 5-Bromo 1-pentene (Fluka), sodium hydroxide (Fluka), potassium iodide (Fluka), potassium carbonate (Aldrich), 4-Fluoro phenol (Fluka), 4Chloro phenol (Fluka), 4-Bromo phenol (Fluka), 4Iodo phenol (Fluka), 1,3-dicyclohexylcarbodiimide (DCC) (Fluka), 4-(N,N-dimethylamino)pyridine (DMAP) (Fluka),

\section{Analytical data of the dyes.}

(1): Ethyl 4-(4-hydroxyphenylazo) benzoate (3).

Ethyl 4-aminobenzoate (1) (46.00 mmol, 1 equiv.) dissolved in methanol $(40 \mathrm{ml})$, cooled the solution to $2^{\circ}$ 

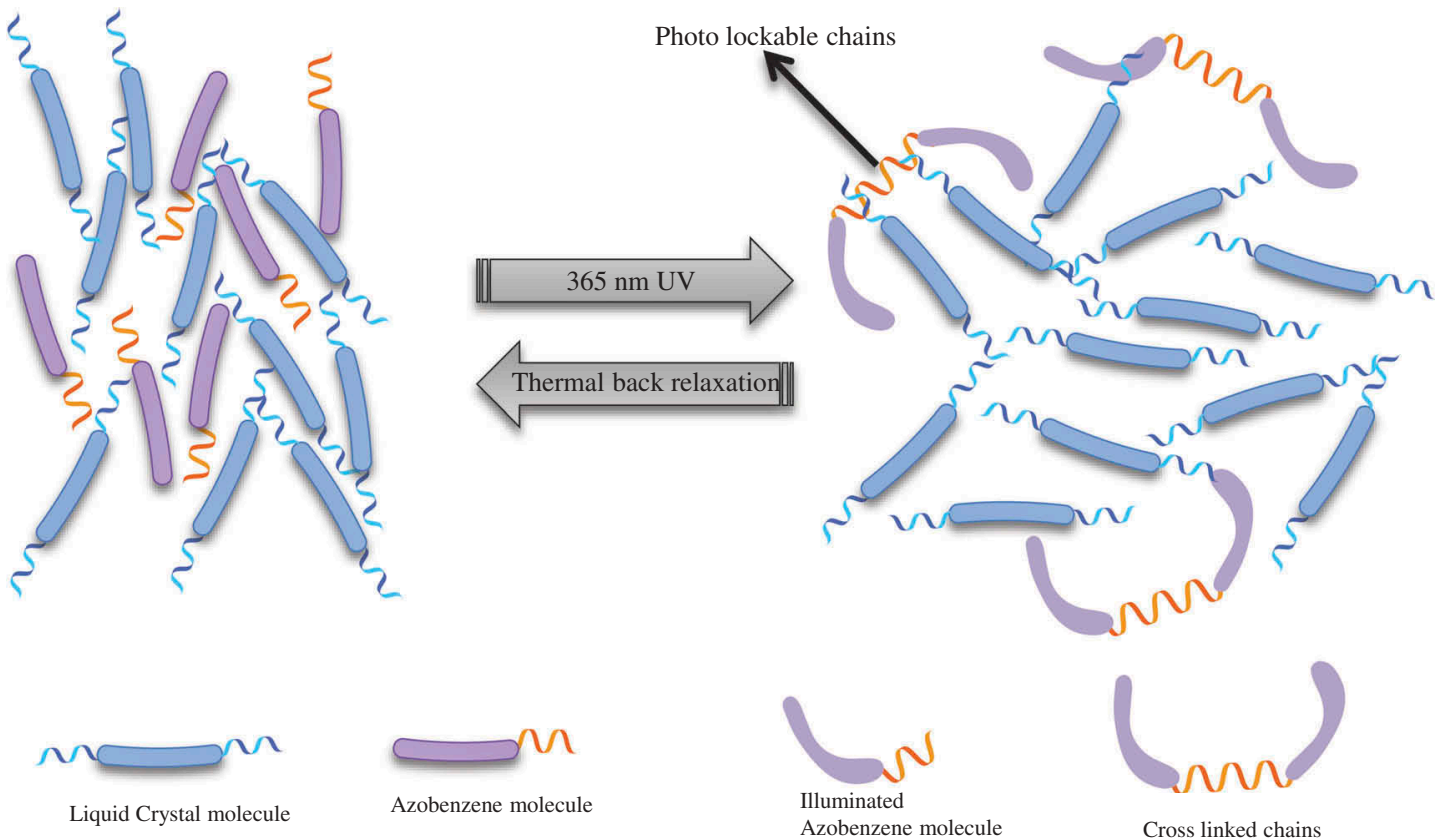

Figure 6. (colour online) Model explaining the mechanism of photolocking when guest-host effects were employed. One can see that due to the formation of intermolecular locking chains; system takes longer time to reverse back to their original shape

C. Hydrochloric acid (25\%) added drop-wise $(8.7 \mathrm{ml})$ to the reaction mixture maintaining sub-zero temperature. $\mathrm{NaNO}_{2}$ dissolved with water $(44.6 \mathrm{mmol}, 1$ equiv.) added drop-wise at $2^{\circ} \mathrm{C}$ and the reaction mixture stirred for $15 \mathrm{~min}$ to produce diazonium ion (2). Finally, the phenol solution in methanol $(44.6 \mathrm{mmol}, 1$ equiv.) added slowly at $2^{\circ} \mathrm{C}$, further bascified using $0.1 \mathrm{~N} \mathrm{NaOH}$ to $\mathrm{pH} 8.5-9$ and the reaction mixture agitated for $4 \mathrm{~h}$.

Diluted the above reaction mixture with cold methanol $(250 \mathrm{ml})$ and acidified to $\mathrm{pH} 4$. The reddish yellow precipitate filtered, dried and recrystallised from methanol.

Reddish-yellow coloured solid; $R_{f}=0.42(40 \%$ $\mathrm{CH}_{2} \mathrm{Cl}_{2}-\mathrm{EtOH}$ ); yield: $62 \%$; m.p.: $160-161^{\circ} \mathrm{C}$; IR $(\mathrm{KBr}) \mathrm{cm}^{-1}: 3321,3186,1728,1602,1484,1248,1140$, 829; ${ }^{1} \mathrm{H}$ NMR (400 MHz, Acetone-d6): $\delta 8.17$ (d, $J=8.2 \mathrm{~Hz}, 2 \mathrm{H}, \mathrm{Ar}), 7.92(\mathrm{~d}, J=7.5 \mathrm{~Hz}, 2 \mathrm{H}, \mathrm{Ar})$, $7.88(\mathrm{~d}, J=7.5 \mathrm{~Hz}, 2 \mathrm{H}, \mathrm{Ar}), 7.01(\mathrm{~d}, J=8.2 \mathrm{~Hz}, 2 \mathrm{H}$, Ar), $5.54(\mathrm{~s}, 1 \mathrm{H}, \mathrm{OH}), \delta 4.42(\mathrm{q}, J=7.2 \mathrm{~Hz}, 2 \mathrm{H}$, $\left.\mathrm{CH}_{2} \mathrm{CH}_{3}\right), 1.44\left(\mathrm{t}, 3 \mathrm{H}, \mathrm{CH}_{2} \mathrm{CH}_{3}\right)$.

(2): Ethyl 4-\{(E)-[4-(pent-4-en-1-yloxy)phenyl]diazenyl\}benzoate (4)

Ethyl 4-(4-hydroxyphenylazo) benzoate (3) (18.5 mmol, 1 equiv.), 5-Bromo 1-pentene (37.1 mmol, 2 equiv.) dissolved in dry acetone $(300 \mathrm{ml})$ and potassium carbonate $(18.5 \mathrm{mmol}$, 1 equiv.) added in portion, also a pinch of potassium iodide added to reaction mixture. The above reaction mixture refluxed for $24 \mathrm{~h}$ under nitrogen atmosphere and confirmed the product formation by TLC, further the solvent removed under reduced pressure using rotavapour, dried the reaction mixture and taken for the next ester hydrolysis reaction.

(3): 4-\{(E)-[4-(Pent-4-en-1-yloxy)phenyl $]$ diazenyl $\}$ benzoic acid (5)

Ethyl 4-\{(E)-[4-(pent-4-en-1-yloxy)phenyl]diazenyl\} benzoate (4) dissolved in $100 \mathrm{ml}$ of methanol and cooled below $5^{\circ} \mathrm{C}$, a aqueous solution of potassium hydroxide (62.2 mmol, 3 equiv.) in water $(20 \mathrm{ml})$ added drop wise, refluxed for $4 \mathrm{~h}$. Further TLC confirmed the completion of reaction, followed by $n$-hexanes washes to remove nonpolar impurities. Further, acidified the aqueous solution with dilute hydrochloric acid to $\mathrm{pH} 6$ and then extracted with ethyl acetate, followed by brine solution wash. Organic ethyl acetate layer dried over anhydrous sodium sulphate and filtered, further the filtrate evaporated under reduced pressure using rotavapour to obtain solid followed by recrystallisation using ethanol: chloroform (2:1) to accomplish pure acid.

A yellow coloured solid; yield: $46 \%$; m.p.: $156-157^{\circ}$ C; IR (KBr) $\mathrm{cm}^{-1}: 2849,2918,3004,1711,2918,1220$, $1588,1493,1248,1130,1092,835 ;{ }^{1} \mathrm{H}$ NMR $(400 \mathrm{MHz}$, DMSO- $\left.\mathrm{d}_{6}\right): \delta 11.10(\mathrm{~s}, 1 \mathrm{H}, \quad \mathrm{OH}), 7.13-8.12(\mathrm{~m}$, $J=8.15 \mathrm{~Hz}, 8 \mathrm{H}, \mathrm{Ar}), 5.93-5.83$ (m, $1 \mathrm{H}$, olefinic), 5.10 - $4.99(\mathrm{~m}, 2 \mathrm{H}$, olefinic), $4.12(\mathrm{t}, J=8.00 \mathrm{~Hz}, 2 \mathrm{H}$, $\left.\mathrm{OCH}_{2}\right), 2.42-2.59\left(\mathrm{~m}, 4 \mathrm{H}, \mathrm{CH}_{2}\right)$.

(4):Phenyl/4-halogen-phenyl4- $\{(E)-[4-($ pent-4-en1-loxy)phenyl]diazenyl\}benzoate derivative $(6-\mathrm{H}$ to 6-I)) 
4-\{(E)-[4-(Pent-4-en-1-yloxy)phenyl]diazenyl\}benzoic acid (5) (15.3 mmol, 1 equiv.) dissolved in $50 \mathrm{ml}$ of dry dichloromethane, DMAP $(1.40 \mathrm{mmol}, 0.1$ equiv.) added and the mixture stirred for $30 \mathrm{~min}$. A solution of either phenol or 4-halogen-phenol ( $15.2 \mathrm{mmol}, 1$ equiv.) in dry dichloromethane $(10 \mathrm{ml})$ added to the mixture. $N, N^{\prime}$-dicyclohexylcarbodiimide (DCC) (23.0 mmol, 1.5 equiv.) in $10 \mathrm{ml}$ of dry dichloromethane added slowly and stirred the reaction mixture for $24 \mathrm{~h}$ at room temperature. The precipitate $N$, $N$ '-dicyclohexylurea filtered off and the filtrate was concentrated, followed by column chromatography (230-400 silica gel) using $\mathrm{CHCl}_{3}: \mathrm{CH}_{3} \mathrm{OH}(9: 0.5)$ as an eluent and further purified by crystallisation from $\mathrm{CHCl}_{3} / \mathrm{CH}_{3} \mathrm{OH}$ (2:1) to afford pale yellow colour solid.

6-H: Phenyl 4-\{(E)-[4-(pent-4-en-1-yloxy)phenyl] diazenyl\}benzoate; pale yellow coloured solid; yield: 64\%; m.p.: $119-121^{\circ} \mathrm{C}$; IR (KBr) cm ${ }^{-1}$ : 3004, 2918, 2849, 1732, 1200, 1143, 1261, 1096, 1072, 859, 838; ${ }^{1} \mathrm{H}$ NMR $\left(400 \mathrm{MHz}, \mathrm{CDCl}_{3}\right): \delta 8.33(\mathrm{~d}, 2 \mathrm{H}, J=8 \mathrm{~Hz}$, Ar), $8.03(\mathrm{~d}, 2 \mathrm{H}, J=8 \mathrm{~Hz}, \operatorname{Ar}), 7.98(\mathrm{~d}, 2 \mathrm{H}, J=8 \mathrm{~Hz}$, Ar), 7.92 (d, $J=8 \mathrm{~Hz}, 2 \mathrm{H}, \mathrm{Ar}), 7.65(\mathrm{~d}, J=8 \mathrm{~Hz}, 1 \mathrm{H}$, Ar), $7.52(\mathrm{~d}, J=8 \mathrm{~Hz}, 2 \mathrm{H}, \mathrm{Ar}), 7.18(\mathrm{~d}, J=8 \mathrm{~Hz}, 2 \mathrm{H}$, Ar), $5.89\left(\mathrm{~m}, 1 \mathrm{H},-\mathrm{CH}=\mathrm{CH}_{2}\right.$, olefinic $), 5.10(\mathrm{~m}, 2 \mathrm{H},-$ $\mathrm{CH}=\mathrm{CH}_{2}$, olefinic $), 4,13\left(\mathrm{~m}, 2 \mathrm{H}, \mathrm{OCH}_{2}\right), 2.23-1.89(\mathrm{~m}$, $2 \mathrm{H}, 2 \times \mathrm{CH}_{2}$ ); EA calc. for $\mathrm{C}_{24} \mathrm{H}_{22} \mathrm{~N}_{2} \mathrm{O}_{3}, 386.44 \mathrm{~g} / \mathrm{mol}$ : calculated (found) \%: C 74.59 (74.50), H 5.74 (5.67), N 7.25 (7.13).

6-F: 4-Fluoro-phenyl 4-\{(E)-[4-(pent-4-en-1-yloxy) phenyl]diazenyl\}benzoate; pale yellow coloured solid; yield: $63 \%$; m.p.: $126-127^{\circ} \mathrm{C}$; IR $(\mathrm{KBr}) \mathrm{cm}^{-1}$ : 3006, 2916, 2848, 1725, 1186, 1143, 1261, 1096, 1072, 858, 838; ${ }^{1} \mathrm{H}$ NMR $\left(400 \mathrm{MHz}, \mathrm{CDCl}_{3}\right): \delta 8.32(\mathrm{~d}, 2 \mathrm{H}$, $J=8 \mathrm{~Hz}, \mathrm{Ar}), 8.02(\mathrm{~d}, 2 \mathrm{H}, J=8 \mathrm{~Hz}, \mathrm{Ar}), 7.97(\mathrm{~d}, 2 \mathrm{H}$, $J=8 \mathrm{~Hz}, \mathrm{Ar}), 7.58(\mathrm{~d}, J=8 \mathrm{~Hz}, 2 \mathrm{H}, \mathrm{Ar}), 7.39(\mathrm{~d}$, $J=8 \mathrm{~Hz}, 2 \mathrm{H}, \mathrm{Ar}), 7.18(\mathrm{~d}, J=8 \mathrm{~Hz}, 2 \mathrm{H}, \mathrm{Ar}), 5.90(\mathrm{~m}$, $1 \mathrm{H},-\mathrm{CH}=\mathrm{CH}_{2}$, olefinic), $5.09\left(\mathrm{~m}, 2 \mathrm{H},-\mathrm{CH}=\mathrm{CH}_{2}\right.$, olefinic), 4,14 (m, $\left.2 \mathrm{H}, \mathrm{OCH}_{2}\right), 2.24-1.88(\mathrm{~m}, 2 \mathrm{H}, 2 \times$ $\mathrm{CH}_{2}$ ); EA calc. for $\mathrm{C}_{24} \mathrm{H}_{21} \mathrm{FN}_{2} \mathrm{O}_{3}, 404.43 \mathrm{~g} / \mathrm{mol}$ : calculated (found) \%: C 71.27 (71.23), H 5.23 (5.19), N 6.93 (6.89).

6-Cl: 4-Chloro-phenyl 4-\{(E)-[4-(pent-4-en-1-yloxy) phenyl]diazenyl $\}$ benzoate; pale yellow coloured solid; yield: $65 \%$; m.p.: $131-132^{\circ} \mathrm{C}$; IR $(\mathrm{KBr}) \mathrm{cm}^{-1}$ : 3006, 2916, 2851,1733, 1259, 1208, 1143, 1092, 1066, 837, 809, ${ }^{1} \mathrm{H}$ NMR (400 MHz, $\left.\mathrm{CDCl}_{3}\right): \delta 8.35(\mathrm{~d}, 2 \mathrm{H}, J=8 \mathrm{~Hz}, \mathrm{Ar})$, $8.01(\mathrm{~d}, 2 \mathrm{H}, J=8 \mathrm{~Hz}, \mathrm{Ar}), 7.96(\mathrm{~d}, 2 \mathrm{H}, J=8 \mathrm{~Hz}, \mathrm{Ar}), 7.57$ $(\mathrm{d}, 2 \mathrm{H}, J=8 \mathrm{~Hz}, \mathrm{Ar}), 7.41(\mathrm{~d}, 2 \mathrm{H}, J=8 \mathrm{~Hz}, \mathrm{Ar}), 7.18$ (d, $J=8 \mathrm{~Hz}, 2 \mathrm{H}, \mathrm{Ar}), 5.88\left(\mathrm{~m}, 1 \mathrm{H},-\mathrm{CH}=\mathrm{CH}_{2}\right.$, olefinic), 5.10 $\left(\mathrm{m}, 2 \mathrm{H},-\mathrm{CH}=\mathrm{CH}_{2}\right.$, olefinic), $4.12\left(\mathrm{~m}, 2 \mathrm{H}, \mathrm{OCH}_{2}\right), 2.22-$ $1.86\left(\mathrm{~m}, 2 \mathrm{H}, 2 \times \mathrm{CH}_{2}\right) ;{ }^{13} \mathrm{C}$ NMR (100 MHz, DMSO): $\delta$ $164.38,162.72,155.59,149.86,149.65,138.35,131.77$, $130.75,130.40,130.00,125.69,124.40,123,115.84$,
$115.71,67.75,30.01,29.55,29.49,29.30$; EA calc. for $\mathrm{C}_{24} \mathrm{H}_{21} \mathrm{ClN}_{2} \mathrm{O}_{3}, 420.89 \mathrm{~g} / \mathrm{mol}$ : calculated (found) \%: $\mathrm{C}$ 68.49 (68.78), H 5.03 (5.29), N 6.66 (6.44).

6-Br: 4-Bromo-phenyl 4-\{(E)-[4-(pent-4-en-1yloxy)phenyl]diazenyl $\}$ benzoate; pale yellow coloured solid; yield: $63 \%$; m.p.: $142-143^{\circ} \mathrm{C}$; IR $(\mathrm{KBr}) \mathrm{cm}^{-1}$ : 3016, 2919, 2848, 1733, 1259, 1208, 1143, 1092, 1066, 837, 809; ${ }^{1} \mathrm{H}$ NMR (400 MHz, $\left.\mathrm{CDC}_{\mathrm{l}}\right):{ }^{1} \mathrm{H}$ NMR $\left(400 \mathrm{MHz}, \mathrm{CDCl}_{3}\right): \delta 8.32(\mathrm{~d}, 2 \mathrm{H}, J=8 \mathrm{~Hz}, \mathrm{Ar}), 8.02$ (d, $2 \mathrm{H}, J=8 \mathrm{~Hz}, \mathrm{Ar}), 7.98(\mathrm{~d}, 2 \mathrm{H}, J=8 \mathrm{~Hz}, \mathrm{Ar}), 7.85$ (d, $2 \mathrm{H}, J=8 \mathrm{~Hz}, \mathrm{Ar}$ ), 7.39 (d, 2H, $J=8 \mathrm{~Hz}, \mathrm{Ar}), 7.17$ (d, $J=8 \mathrm{~Hz}, 2 \mathrm{H}, \mathrm{Ar}), 5.90\left(\mathrm{~m}, 1 \mathrm{H},-\mathrm{CH}=\mathrm{CH}_{2}\right.$, olefinic), $5.07\left(\mathrm{~m}, 2 \mathrm{H},-\mathrm{CH}=\mathrm{CH}_{2}\right.$, olefinic $), 4.12(\mathrm{t}, J=8.1 \mathrm{~Hz}$, $\left.2 \mathrm{H}, \mathrm{OCH}_{2}\right), 2.24-1.84\left(\mathrm{~m}, 2 \mathrm{H}, 2 \times \mathrm{CH}_{2}\right)$; EA calc. for $\mathrm{C}_{24} \mathrm{H}_{21} \mathrm{BrN}_{2} \mathrm{O}_{3}, 465.34 \mathrm{~g} / \mathrm{mol}$ : calculated (found) \%: C 61.95 (62.01), H 4.55 (4.29), N 6.02 (6.14).

6-I: 4-Iodo-phenyl 4-\{(E)-[4-(pent-4-en-1-yloxy) phenyl]diazenyl\}benzoate; pale yellow coloured solid; yield: $64 \%$; m.p.: $158-159^{\circ} \mathrm{C}$; IR $(\mathrm{KBr}) \mathrm{cm}^{-1}$ : 3033 , 2916, 2848, 1731, 1257, 1205, 1139, 1068, 1052, 859, 836; ${ }^{1} \mathrm{H}$ NMR $\left(400 \mathrm{MHz}, \mathrm{CDCl}_{3}\right):{ }^{1} \mathrm{H}$ NMR $(400 \mathrm{MHz}$, $\left.\mathrm{CDCl}_{3}\right): \delta 8.33(\mathrm{~d}, 2 \mathrm{H}, J=8 \mathrm{~Hz}, \mathrm{Ar}), 8.01(\mathrm{~d}, 2 \mathrm{H}$, $J=8 \mathrm{~Hz}, \operatorname{Ar}), 7.98(\mathrm{~d}, 2 \mathrm{H}, J=8 \mathrm{~Hz}, \operatorname{Ar}), 7.70(\mathrm{~d}, 2 \mathrm{H}$, $J=8 \mathrm{~Hz}, \mathrm{Ar}), 7.35(\mathrm{~d}, 2 \mathrm{H}, J=8 \mathrm{~Hz}, \mathrm{Ar}), 7.18(\mathrm{~d}$, $J=8 \mathrm{~Hz}, 2 \mathrm{H}, \mathrm{Ar}), 5.88\left(\mathrm{~m}, 1 \mathrm{H},-\mathrm{CH}=\mathrm{CH}_{2}\right.$, olefinic), $5.10\left(\mathrm{~m}, 2 \mathrm{H},-\mathrm{CH}=\mathrm{CH}_{2}\right.$, olefinic), $4.12(\mathrm{t}, J=8 \mathrm{~Hz}, 2 \mathrm{H}$, $\left.\mathrm{OCH}_{2}\right), 2.22-1.85\left(\mathrm{~m}, 2 \mathrm{H}, 2 \times \mathrm{CH}_{2}\right)$; EA calc. for $\mathrm{C}_{24} \mathrm{H}_{21} \mathrm{IN}_{2} \mathrm{O}_{3}, 512.34 \mathrm{~g} / \mathrm{mol}$ : calculated (found) \%: C 56.26 (55.96), H 4.13 (4.28), N 5.47 (5.19).

\section{Disclosure statement}

No potential conflict of interest was reported by the authors.

\section{Funding}

We sincerely thanks to Department of Science and Technology-Science and Engineering Research Board for providing young career research award grant ECR/2015/ 000190 .

\section{References}

[1] Rahman ML, Yusoff MM, Kumar S. Synthesis and photoswitching properties of liquid crystals derived from myo-inositol. RSC Adv. 2014;4(66):35089-35098. doi:10.1039/C4RA05568C.

[2] Rahman ML, Hegde G, Azazpour M, et al. Synthesis and characterization of liquid crystalline azobenzene chromophores with fluorobenzene terminal. J Fluorine Chem. 2013;156:230-235. doi:10.1016/j.jfluchem.2013. 10.004 .

[3] Rahman L, Kumar S, Tschierske C, et al. Synthesis and photoswitching properties of bent-shaped liquid crystals 
containing azobenzene monomers. Liq Cryst. 2009;36 (4):397-407. doi:10.1080/02678290902923428.

[4] Lutfor MR, Hegde G, Kumar S, et al. Synthesis and characterization of bent-shaped azobenzene monomers: guest-host effects in liquid crystals with azo dyes for optical image storage devices. Opt Mater. 2009;32 (1):176-183. doi:10.1016/j.optmat.2009.07.006.

[5] Sun J, Chigrinov V. Effect of azo dye layer on rewriting speed of optical rewritable E-paper. Mol Cryst Liq Cryst. 2012;561(1):1-7. doi:10.1080/15421406.2012.686690.

[6] Hou L, Mennig M, Schmidt HK. Photochromic organicinorganic composite materials prepared by sol-gel processing: properties and potentials. In: Wittwer V, Granqvist CG, Lampert CM, editors. Proceeding of SPIE 2255, Optical materials technology for energy efficiency and solar energy conversion XIII; 1994 Sep 9. International Society for Optics and Photonics; 1994. p. 26-37. doi:10.1117/12.185377

[7] Prasad SK, Nair GG, Rao DS. Photoinduced phase transitions. Liq Cryst. 2009;36(6-7):705-716. doi:10.1080/ 02678290902755572.

[8] Yuvaraj AR, Yam WS, Chan TN, et al. New para-substituted non-symmetric isoflavones for their fast photoswitching ability: synthesis and their liquid crystal characterization. Spectrochim Acta Mol Biomol Spectrosc. 2015;135:1115-1122. doi:10.1016/j.saa.2014.08.009.

[9] Gan SM, Pearl ZF, Yuvaraj AR, et al. Polarity dependent photoisomerization of ether substituted azodyes: synthesis and photoswitching behavior. Spectrochim Acta Mol Biomol Spectrosc. 2015;149:875-880. doi:10.1016/ j.saa.2015.05.027.

[10] Gan SM, Yuvaraj AR, Lutfor MR, et al. Synthesis, liquid crystal characterization and photo-switching studies on fluorine substituted azobenzene based esters. RSC Adv. 2015;5(9):6279-6285. doi:10.1039/C4RA13700K.

[11] Sidharth SN, Yuvaraj AR, Hui TJ, et al. Light induced properties of chalcones correlated with molecular structure and photophysical properties for permanent optical storage device. Adv Mater Res. 2014;1033-1034:11491153. doi:10.4028/www.scientific.net/AMR.1033-1034.

[12] Gindre D, Boeglin A, Fort A, et al. Rewritable optical data storage in azobenzene copolymers. Opt Express. 2006;14(21):9896-9901. doi:10.1364/OE.14.009896.

[13] Alaasar M, Prehm M, Tschierske C. New azobenzene containing bent-core liquid crystals based on disubstituted resorcinol. Liq Cryst. 2014;41(1):126-136. doi:10.1080/ 02678292.2013.840393.

[14] Alaasar M, Prehm M, Nagaraj M, et al. A liquid crystalline phase with uniform tilt, local polar order and capability of symmetry breaking. Adv Mater. 2013;25 (15):2186-2191. doi:10.1002/adma.201205180.

[15] Alaasar M, Prehm M, Tschierske C. Influence of halogen substituent on the mesomorphic properties of fivering banana-shaped molecules with azobenzene wings. Liq Cryst. 2013;40(5):656-668. doi:10.1080/02678292. 2013.767949.

[16] Alaasar M, Prehm M, Tschierske C. A new room temperature dark conglomerate mesophase formed by bentcore molecules combining 4-iodoresorcinol with azobenzene units. Chem Commun. 2013;49(94):1106211064. doi:10.1039/c3cc45938a.
[17] Alaasar M, Prehm M, May K, et al. 4-Cyanoresorcinolbased bent-core mesogens with azobenzene wings: emergence of sterically stabilized polar order in liquid crystalline phases. Adv Funct Mater. 2014;24(12):17031717. doi:10.1002/adfm.v24.12.

[18] Alaasar M, Prehm M, Brautzsch $M$, et al. 4Methylresorcinol based bent-core liquid crystals with azobenzene wings - a new class of compounds with dark conglomerate phases. J Mater Chem C. 2014;2 (28):5487-5501. doi:10.1039/C4TC00533C.

[19] Alaasar M, Prehm M, Brautzsch M, et al. Dark conglomerate phases of azobenzene derived bent-core mesogens-relationships between the molecular structure and mirror symmetry breaking in soft matter. Soft Mater. 2014;10(37):7285-7296. doi:10.1039/C4SM0 $1255 \mathrm{~K}$.

[20] Zhao Y, Ikeda T, editors. Smart light-responsive materials: azobenzene-containing polymers and liquid crystals. Hoboken (NJ): John Wiley \& Sons. 2009.

[21] Goodby JW, Mandle RJ, Davis EJ, et al. What makes a liquid crystal? The effect of free volume on soft matter. Liq Cryst. 2015;42(56):593-622.

[22] Naoum MM, Fahmi AA, Ahmed NHS, et al. The effect of inversion of the ester group on the mesophase behaviour of some azo/ester compounds. Liq Cryst. 2015;42 (9):1298-1308.

[23] Naoum MM, Fahmi AA, Abaza AH, et al. Effect of exchange of terminal substituents on the mesophase behaviour of some azo/ester compounds. Liq Cryst. 2014;41 (11):1559-1568. doi:10.1080/02678292.2014.934308.

[24] Podruczna M, Hofmańska A, Niezgoda I, et al. Influence of terminal groups on liquidcrystalline polymorphism of selected azobenzene derivatives. Liq Cryst. 2014;41(1):113-125. doi:10.1080/02678292.2013.839834.

[25] Hagen R, Bieringer T. Photoaddressable polymers for optical data storage. Adv Mater. 2001;13(23):1805-1810. doi:10.1002/(ISSN)1521-4095.

[26] Natansohn A, Rochon P. Photoinduced motions in azocontaining polymers. Chem Rev. 2002;102(11):41394176. doi:10.1021/cr970155y.

[27] Shannon PJ, Gibbons WM, Sun ST. Patterned optical properties in photopolymerized surface-aligned liquidcrystal films. Nature 1994;368(6471):532-533.

[28] Hikmet RAM, Lub J, Maassen van der Brink P. Structure and mobility within anisotropic networks obtained by photopolymerization of liquid crystal molecules. Macromolecules. 1992;25(16):4194-4199. doi:10. 1021/ma00042a021.

[29] Sévigny S, Bouchard L, Motallebi S, et al. Azobenzene polymer stabilized ferroelectric liquid crystals: simultaneous photopolymerization and photoalignment. Liq Cryst. 2005;32(5):599-607. doi:10.1080/02678290500116813.

[30] Seki T, Tanaka K, Ichimura K. Photopolymerization of diacetylene Langmuir-Blodgett films on an azobenzenecontaining monolayer. Polym J. 1998;30(8):646-652. doi:10.1295/polymj.30.646.

[31] $\mathrm{Pu} \mathrm{X,} \mathrm{Wong} \mathrm{N-B,} \mathrm{Zhou} \mathrm{G,} \mathrm{et} \mathrm{al.} \mathrm{Substituent} \mathrm{effects} \mathrm{on}$ the trans/cis isomerization and stability of diazenes. Chem Phys Lett. 2005;408(1-3):101-106. doi:10.1016/j. cplett.2005.04.011. 
[32] Bronner C, Tegeder P. Photo-induced and thermal reactions in thin films of an azobenzene derivative on $\mathrm{Bi}$ (111). New J Phys. 2014;16(5):053004. doi:10.1088/13672630/16/5/053004.

[33] Yeap G-Y, Osman F, Imrie CT. Non-symmetric dimers: effects of varying the mesogenic linking unit and terminal substituent. Liq Cryst. 2015;42(4):543-554. doi:10.1080/ 02678292.2015.1004843.

[34] Yeap G-Y, Lee H-C, Mahmood WAK, et al. Synthesis, thermal and optical behaviour of non-symmetric liquid crystal dimers $a$-(4-benzylidene-substituted-aniline-4'oxy)- $\omega$-[pentyl-4-(4'-phenyl)benzoateoxy]hexane. Phase Transitions. 2011;84(1):29-37. doi:10.1080/01411594. 2010.513613.

[35] Yeap GY, Hng TC, Yeap SY, et al. Why do nonsymmetric dimers intercalate? The synthesis and characterisation of the $\alpha$ (4benzylidenesubstituted aniline4'oxy) $\omega$ (2methylbu tyl4'(4"phen yl)benzoateoxy)alkanes. Liq Cryst. 2009;36 (12):1431-1441.

[36] Imrie CT, Taylor L. The preparation and properties of low molar mass liquid crystals possessing lateral alkyl chains. Liq Cryst. 1989;6(1):1-10. doi:10.1080/02678298908027317.

[37] Rau H. Azocompounds. In Dürr H, Bouas-Laurent H, editors. Chapter 4, Photochromism-Molecules and Systems. Amsterdam: Elsevier; 1990.

[38] Wei-Guang Diau E. A new trans-to-cis photoisomerization mechanism of azobenzene on the $S 1\left(n, \pi^{\star}\right)$ surface. J Phys Chem. 2004;108(6):950-956. doi:10.1021/jp031149a.

[39] Bortolus P, Monti S. Cis-trans photoisomerization of azobenzene. Solvent and triplet donors effects. J Phys Chem. 1979;83(6):648-652. doi:10.1021/j100469a002.

[40] Pavia D, Lampman G, Kriz G, et al. Introduction to spectroscopy. Boston (MA): Cengage Learning; 2008.
[41] Feringa BL, Jager WF, De Lange B. Organic materials for reversible optical data storage. Tetrahedron. 1993;49 (37):8267-8310. doi:10.1016/S0040-4020(01)81913-X.

[42] Bandara HD, Burdette SC. Photoisomerization in different classes of azobenzene. Chem Soc Rev. 2012;41 (5):1809-1825. doi:10.1039/C1CS15179G.

[43] Sasaki T, Ikeda T, Ichimura K. Photoisomerization and thermal isomerization behavior of azobenzene derivatives in liquid-crystalline polymer matrixes. Macromolecules. 1993;26(1):151-154. doi:10.1021/ma00053a023.

[44] Niezgoda I, Jaworska J, Pociecha D, et al. The kinetics of the EZE isomerisation and liquidcrystalline properties of selected azobenzene derivatives investigated by the prism of the ester group inversion. Liq Cryst. 2015;42 (8):1148-1158. doi:10.1080/02678292.2015.1031198.

[45] Yagci Y, Jockusch S, Turro NJ. Photoinitiated polymerization: advances, challenges, and opportunities. Macromolecules. 2010;43(15):6245-6260. doi:10.1021/ ma1007545.

[46] Burdick DL, Leffler WL. Petrochemicals in nontechnical language. Morris Plains (NJ): Pennwell Books; 2001.

[47] Choe E, Min DB. Chemistry and reactions of reactive oxygen species in foods. Crit Rev Food Sci Nutr. 2006;46(1):1-22. doi:10.1080/10408390500455474.

[48] Min DB, Boff JM. Chemistry and reaction of singlet oxygen in foods. Compr Rev Food Sc Food Saf. 2002;1 (2):58-72. doi:10.1111/crfs.2002.1.issue-2.

[49] Bamford CH, Ledwith A, Yagci Y. Synthesis and reactions of polymers with photoactive terminal groups: 2. New azo-initiator for the synthesis of polymers with $\mathrm{N}$-acyldibenz [b,f] azepine terminal units. Polymer. 1978;19(3):354-356. doi:10.1016/ 0032-3861(78)90234-3. 